\title{
Analysis of the Effect of Financial Performance, Company Size on Stock Prices with Dividend Policy as Moderating Variable in Pharmaceutical Companies Listed on the Indonesia Stock Exchange 2013-2019
}

\author{
Watikah Sururi $^{1}$, Idhar Yahya ${ }^{1}$, Erwin Abubakar ${ }^{1}$ \\ ${ }^{1}$ Department of Accounting, Faculty of Economics and Business at Universitas Sumatera Utara, Indonesia
}

Corresponding Author: Watikah Sururi

\begin{abstract}
Financial instrument shares as part-ownership rights of a company which is evidence of or participation in a company. This study analyzes the effect of profitability, solvency, activity liquidity, and company size on pharmaceutical companies listed on the Indonesian stock exchange for 2013 - 2019. This study will also examine the dividend policy variable used as the moderating variable in the research model.

The population is pharmaceutical companies listed on the Indonesia Stock Exchange for the period 2013 - 2019. All populations in this study were used as research samples of as many as nine companies. Moreover, the number of observations used was 63 observations. The type of data used is secondary data and the data analysis technique used in Panel Data Regression Analysis and Interaction Moderating Test with the help of EViews10 software.

This study indicates that at alpha five percent, profitability and firm size have a significant positive effect on stock prices. In contrast, solvency, liquidity, and activity ratios have no significant effect on stock prices. This study also shows that dividend policy can strengthen the influence of solvency and liquidity on stock prices. However, dividend policy cannot moderate profitability, activity, firm size on stock prices.
\end{abstract}

Keywords: Profitability, solvency, liquidity, activity, company size, dividend policy, stock price.

\section{INTRODUCTION}

The share price of a business entity is an indicator that reflects the company's performance. In general, stock prices that are high or increasing every period reflect the value of the company's or business entity's performance in good condition. On the other hand, a relatively low or declining share price reflects the value of the company's or entity's performance declining or in bad condition. Stocks are one of the most sought-after financial instruments by investors. Therefore, investors need the information to assess, evaluate and compare conditions and changes in an entity as a basis for making decisions.

Performance can also be interpreted as "the work" of a person or group of people in the organization (Rudianto, 2013). According to (Al-Tamimi \& Kalli 2009), investors will generally choose companies with good financial performance. According to Mulyadi (2010), performance appraisal is the periodic determination of an organization's operational effectiveness, part of the organization, and its employees based on the goals, standards, and criteria that have been set previously. In contrast, the purpose of performance appraisal is to motivate employees to achieve organizational goals and comply with predetermined standards of behavior to 
produce the desired actions and results. According to Rudianto (2013), to assess a company's performance, performance measures can be divided into several groups: liquidity ratio, solvency/leverage ratio, profit/profitability ratio, and activity ratio. In this study, the ratios used are only three categories: profitability ratios, solvency ratios, and liquidity ratios.

Stocks are also one of the indicators forming the value of the company. It can be said that shares are securities issued by a company in the form of a limited liability company (issuer). If an investor buys shares, he becomes the company's owner. The price of a company's shares is not only by mentioning a certain number of rupiah figures without any basis. The share price will be reflected in the initial capital when a company is founded. After the company was established, operated, and developed well, the company began to provide results in cash dividends, bonus shares, trademarks, goodwill, earning power, thus also the development of the company's assets, both current and non-current assets. The rise and fall of stock prices in pharmaceutical subsector manufacturing companies from 2015 to 2018 became an interesting phenomenon to be raised in research which can be seen in the following figure 1.1:

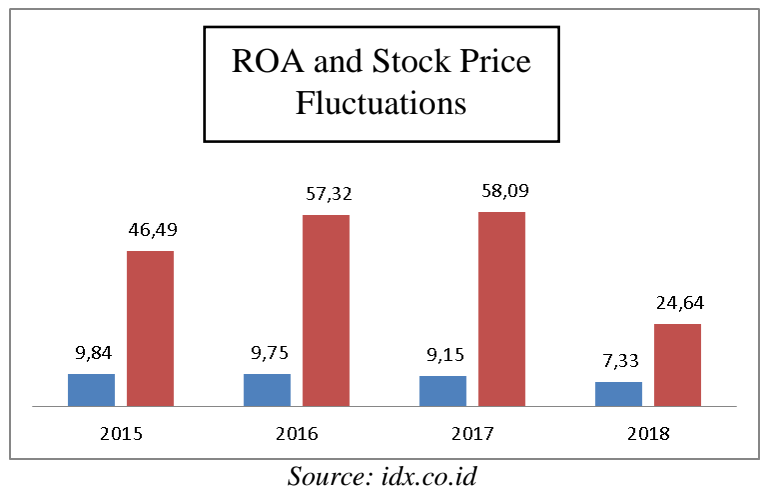

Picture 1: ROA and Stock Price Fluctuations

The following is the average profitability of pharmaceutical sub-sector manufacturing companies in 2015-2018 as measured using ROA. According to signaling theory, when profitability increases, stock prices will rise. However, this is not following Figure 1.1, wherein in 2015-2016, there was a decline in profitability, while in 2015-2016, the stock price increased. Then there was a decline in profitability again in 2017-2018. However, in 2016-2017 the share price increased to 58.08 and finally decreased in 2018 to 24.64. In this explanation, it can be seen that there is a theoretical gap between accounting theory and existing research data, so researchers are interested in testing it again.

Profitability is a ratio of management effectiveness that can be seen from the return on sales and investment, which is the company's ability to earn profits (Dessyana, 2016).

The solvency ratio is shown to see the long-term ability of the company to meet its obligations (Ross, Westerfield, Radolph, \& Jordan, 2009). Kasmir (2015) states that the solvency ratio is a ratio used to measure the extent to which the company's assets are financed by debt. It means how the company bears much debt burden compared to its assets. Thus in a broad sense, it is said that the solvency ratio is used to measure the company's ability to pay all its obligations, both short-term and long-term, if the company is dissolved (liquidated).

According to Brigham \& Joel (2010), the liquidity ratio is a ratio that shows the relationship between cash and other company's current assets with their current liabilities.

The activity ratio measures the company's performance appraisal, which is intended to measure its effectiveness using its funding sources, such as total asset turnover, receivable turnover, every collection period, inventory turnover, and working capital turnover.

Company size is a scale used by companies to classify the company's size in several ways, such as log size, total assets, and others. The size of the company will affect the ability to bear the risks of various situations that may be faced by the company (Prasetyorini, 2013). 
Dividend policy or Dividend Policy determines how much of the profits must be paid to shareholders and how much must be reinvested in the company (Utari, Purwanti, \& Prawironegoro, 2014). A dividend policy is a company's policy for paying income as dividends rather than retaining them for company reinvestment (Hussainey, Mgbame, \& Chijoke-Mgbame, 2011). In line with that, dividends are also payments from the company to shareholders for their profits. Dividend policy is related to the size of the dividend payout ratio, namely the percentage of net profit after tax which is distributed as dividends to shareholders (Sudana, 2015).

Dividends are given after obtaining approval from the shareholders at the general meeting of shareholders (GMS). The dividend decision is part of the company's spending decisions, especially concerning the company's internal spending. It is because the size of the dividends distributed will affect the size of retained earnings.

\section{Previous Research Review}

The research of Meythi et al. (2011) shows that liquidity and profitability significantly affect stock prices. Susilawati's research (2012) shows that solvency and profitability significantly affect stock prices, while liquidity does not affect stock prices. Pranata \& Kurnia's research (2013) shows that profitability affects stock prices, while liquidity and solvency do not affect. Dewi's research (2015) shows that profitability significantly affects stock prices, while liquidity has no significant effect on stock prices. Darmawan (2016) shows that Liquidity, Solvency, and Profitability have a significant effect on stock prices. Dessyana's research (2016) shows that liquidity and profitability significantly affect stock returns, while solvency has no significant effect on stock returns. Adipalguna \& Suarjaya (2016) show that liquidity, solvency, and profitability have no significant effect on stock prices. Arifin \& Agustami's research (2016) shows that profitability significantly affects stock prices, while liquidity and solvency have no significant effect on stock prices.

The results of Suryawan \& Wirajaya's research (2017) show that Return on Assets has a significant effect on stock prices, while the Current Ratio and Debt To Equity Ratio have no significant effect on stock prices. Sambelay \& Rate (2017) shows that Return on Assets has a significant effect on stock prices while Net Profit Margin has no significant effect on stock prices. Octaviani \& Komalasari's research (2017) shows that profitability significantly affects stock prices, while liquidity and solvency have no significant effect on stock prices.

The results of Ramadhani \& Zannati's research (2018) show that Profitability and Liquidity have a significant effect on stock prices while Solvency has no significant effect on stock prices. Levina \& Dermawan's research (2019) shows that Liquidity, Solvency, and Profitability have a significant effect on stock prices while firm size has a positive and significant effect on firm value. The results of Hidayat's research (2019) state that firm size has no significant effect on firm value. Stevani \& Pernamasari's research (2019) states that firm size has a negative and insignificant effect on firm value. Murniati (2016) and Gunarso (2014) find that firm size positively affects stock prices. Rahmandia's (2013) results show that company size has a positive but not significant effect on stock prices. It can be seen that the size of a company affects stock price movements but cannot increase stock prices.

\section{Framework}

Following the description of the background of the problem, literature review, and previous research, a conceptual research framework is prepared as follows: 


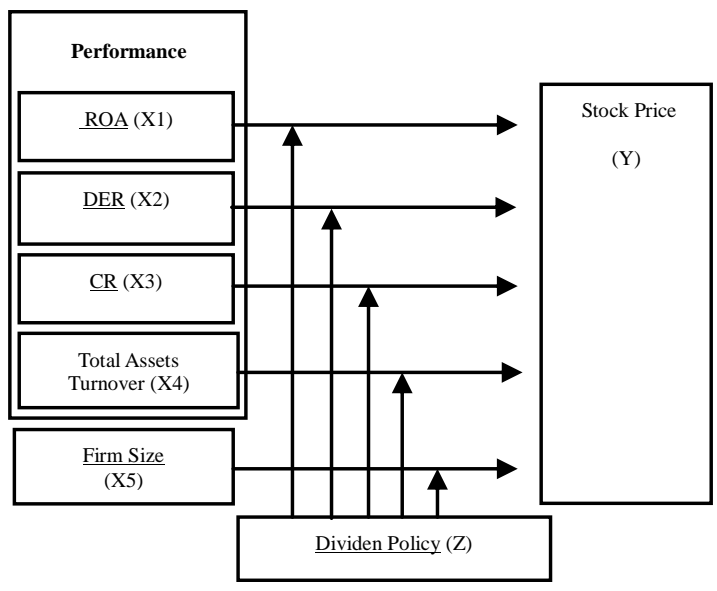

Figure 2. Conceptual Framework

H1: Profitability has a significant effect on stock prices.

$\mathrm{H} 2$ : Solvency has a significant effect on stock prices.

H3: Liquidity has a significant effect on stock prices.

H4: Activity ratio has a significant effect on stock prices.

H5: Company size has a significant effect on stock prices.

H6: Dividend policy can moderate the effect of profitability on stock prices.

H7: Dividend policy can moderate the effect of solvency on stock prices.

H8: Dividend policy can moderate the effect of liquidity on stock prices.

H9: Dividend policy can moderate the effect of activity ratio on stock prices.

H10: Dividend policy can moderate the effect of firm size on stock prices.

\section{RESEARCH METHODS}

This type of research is causal associative research to determine the effect of Financial Performance and Company Size as an independent variable on the dependent variable, namely Stock Price with Dividend Policy as the moderating variable. The causal associative study analyzes the relationship between one variable and another to know how one variable affects other variables (Erlina, 2011). The data analysis technique used in Panel Data Regression Analysis and Interaction Moderating Test with the help of EViews10 software. The population used in this study is all nine pharmaceutical companies listed on the Indonesia Stock Exchange during the 2013-2019 period. Furthermore, the number of observations used was 63 observations.

\section{RESULT AND DISCUSSION Normality test}

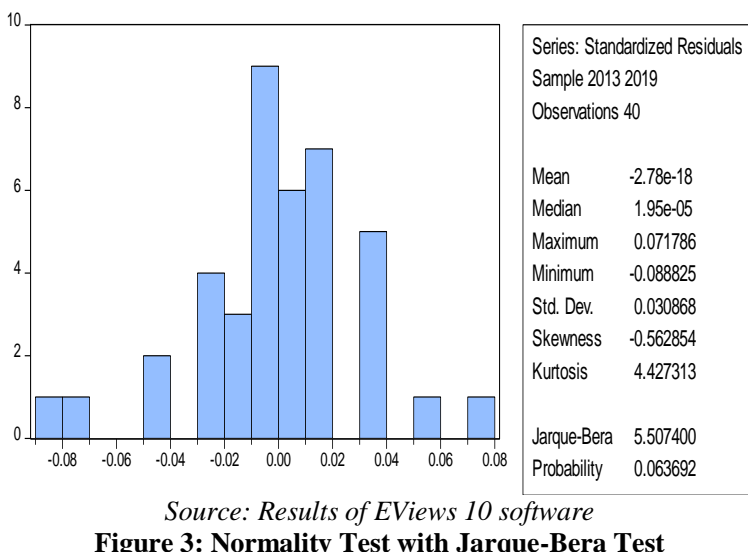

Based on Figure 3, it is known that the probability value of the J-B statistic is 5.507400. Because the probability value, which is 5.507400 , is greater than the significance level, which is 0.05 , the assumption of normality is fulfilled.

\section{Determination of the Estimation Model between the Common Effect Model (CEM) and Fixed Effect Model (FEM) with the Chow. Test}

\section{Common Effect Model (CEM) Test}

\begin{tabular}{|c|c|c|c|c|}
\hline \multicolumn{5}{|c|}{$\begin{array}{l}\text { Table 1. Effect Mo } \\
\text { Dependent Variable: } Y \\
\text { Method: Panel Least Squares } \\
\text { Date: } 04 / 06 / 21 \text { Time: } 00: 59 \\
\text { Sample: } 20132019 \\
\text { Periods included: } 7 \\
\text { Cross-sections included: } 9 \\
\text { Total panel (balanced) observations: } 63\end{array}$} \\
\hline Variable & Coefficient & Std. Error & $\mathrm{t}$-Statistic & Prob. \\
\hline c & 45514.42 & 24497.74 & 1.857903 & 0.0684 \\
\hline $\mathrm{X} 1$ & 235168.9 & 66840.11 & 3.518379 & 0.0009 \\
\hline$\times 2$ & -6919.440 & 1959.807 & -3.530673 & 0.0008 \\
\hline$x_{3}$ & 3219.228 & 2996.267 & 1.074413 & 0.2872 \\
\hline$\times 4$ & 1969.255 & 12771.34 & 0.154193 & 0.8780 \\
\hline $\begin{array}{l}14 \\
\times 5\end{array}$ & -1890.680 & 862.3751 & -2.192410 & 0.0325 \\
\hline $\mathrm{z}$ & -81212.89 & 44904.58 & -1.808566 & 0.0759 \\
\hline R-squared & 0.356887 & \multicolumn{2}{|c|}{ Mean dependent var } & 10500.40 \\
\hline Adjusted R-squared & & \multicolumn{2}{|c|}{ S.D. dependent var } & 31295.23 \\
\hline S.E. of regression & 26407.28 & \multirow{2}{*}{\multicolumn{2}{|c|}{ Akaike info criterion }} & 23.30511 \\
\hline Sum squared resid & $3.91 \mathrm{E}+10$ & & & 23.54323 \\
\hline Log likelihood & -727.1108 & \multicolumn{2}{|c|}{$\begin{array}{l}\text { Schwarz criterion } \\
\text { Hannan-Quinn criter. }\end{array}$} & 23.39876 \\
\hline F-statistic & 5.179405 & \multicolumn{2}{|c|}{$\begin{array}{l}\text { Hannan-Quinn criter. } \\
\text { Durbin-Watson stat }\end{array}$} & 0.652741 \\
\hline Prob(F-statistic) & 0.000269 & & & \\
\hline
\end{tabular}

Source: Results of EViews 10 software 
Watikah Sururi et.al. Analysis of the effect of financial performance, company size on stock prices with dividend policy as moderating variable in pharmaceutical companies listed on the Indonesia Stock Exchange 2013-2019.

Fixed Effect Model (FEM) Test

Table 2 Test of Fixed Effect Model

\begin{tabular}{crrrr}
\hline \hline Variable & Coefficient & Std. Error & t-Statistic & Prob. \\
\hline \hline X1 & 331404.9 & 117753.4 & 2.814398 & 0.0071 \\
X2 & 1539.905 & 4418.420 & 0.348519 & 0.7290 \\
X3 & -242.2377 & 3749.642 & -0.064603 & 0.9488 \\
X4 & -16765.86 & 16155.66 & -1.037770 & 0.3046 \\
X5 & -4428.096 & 13495.78 & -0.328110 & 0.7443 \\
Z & -132257.1 & 47014.63 & -2.813105 & 0.0071 \\
C & 107862.8 & 339885.6 & 0.317350 & 0.7524 \\
\hline \hline \multicolumn{5}{c}{ Effects Specification } \\
\hline \hline
\end{tabular}

Cross-section fixed (dummy variables)

\begin{tabular}{lrll} 
R-squared & 0.555956 & Mean dependent var & 10500.40 \\
Adjusted R-squared & 0.426443 & S.D. dependent var & 31295.23 \\
S.E. of regression & 23700.99 & Akaike info criterion & 23.18868 \\
Sum squared resid & $2.70 \mathrm{E}+10$ & Schwarz criterion & 23.69895 \\
Log likelihood & -715.4434 & Hannan-Quinn criter. & 23.38937 \\
F-statistic & 4.292663 & Durbin-Watson stat & 1.058271 \\
Prob(F-statistic) & 0.000074 & & \\
\hline \hline
\end{tabular}

Source: Results of EViews 10 software

\section{Chow test}

Table 3 Chow test

\begin{tabular}{lrrr}
\hline \hline Effects Test & Statistic & d.f. & Prob. \\
\hline \hline Cross-section F & 2.689849 & $(8,48)$ & 0.0158 \\
Cross-section Chi-square & 23.334950 & 8 & 0.0030 \\
\hline \hline
\end{tabular}

Source: Results of EViews 10 software

In the table of the results of the Chow test analysis, the probability value of Cross-section $\mathrm{F}$ is 0.02 and chi-square is 0.00 so that $\mathrm{H} 0$ is rejected and $\mathrm{H} 1$ is accepted. Then the Fixed Effect Model is accepted so that the Random Effect Model test is then carried out.

\section{Random Effect Model Test}

\begin{tabular}{crrrr}
\multicolumn{6}{c}{ Table 4 Test of Random Effect Model } \\
\hline \hline Variable & Coefficient & Std. Error & t-Statistic & Prob. \\
\hline \hline X1 & 235708.5 & 63056.13 & 3.738075 & 0.0004 \\
X2 & -6835.063 & 1875.044 & -3.645281 & 0.0006 \\
X3 & 3416.380 & 2742.256 & 1.245828 & 0.2180 \\
X4 & 700.9161 & 11576.22 & 0.060548 & 0.9519 \\
X5 & -1824.209 & 841.0515 & -2.168962 & 0.0343 \\
Z & -89937.87 & 40924.72 & -2.197642 & 0.0321 \\
C & 44644.96 & 23666.58 & 1.886414 & 0.0644 \\
\hline \hline
\end{tabular}

Source: Results of EViews 10 software

\section{Hausman test}

\begin{tabular}{lrrr}
\multicolumn{5}{c}{ Table 5 Hausman Test } & & \\
\hline \hline Test Summary & Chi-Sq. Statistic & Chi-Sq. d.f. & Prob. \\
\hline \hline Cross-section random & 16.810874 & 6 & 0.0100 \\
\hline \hline
\end{tabular}

Source: Results of EViews 10 software
From the following table, the results of the Hausman test analysis show that the Chi-Square probability value is 0.01 so $<0.05$, then what is accepted is the Fix Effect Model so that the research model used is the Random Effect Model.

\section{Hypothesis test Multiple Regression Analysis}

\begin{tabular}{crrrr}
\multicolumn{5}{c}{ Table 6 Multiple Regression Analysis } \\
\hline \hline Variable & Coefficient & Std. Error & t-Statistic & Prob. \\
\hline C & -10.06505 & 3.892085 & -2.586030 & 0.0128 \\
LNX1 & 0.050358 & 0.009399 & 5.357764 & 0.0000 \\
LNX2 & 0.013521 & 0.019672 & 0.687354 & 0.4952 \\
LNX3 & -0.004790 & 0.017955 & -0.266813 & 0.7908 \\
LNX4 & 0.057788 & 0.034084 & 1.695444 & 0.0965 \\
LNX5 & 3.865304 & 1.228246 & 3.147011 & 0.0028 \\
LNZ & 0.037702 & 0.008592 & 4.387809 & 0.0001 \\
\hline \hline \multicolumn{5}{c}{ Source: Results of EViews 10 software }
\end{tabular}

From the attached table, the results of the CEM analysis test are obtained as follows:

$Y_{1}=\beta_{0 i t} \alpha+\beta_{1} X_{1 i t}+\beta_{2} X_{2 i t}+\beta_{3} X_{i t 3}+\beta_{4} X_{4 i t}$ $+\beta_{5} X_{5 i t}+\mathbf{e}_{1 i t}$

$\mathrm{HS}=-10.065+0.05 \mathrm{ROA}+0.014 \mathrm{DER}-$ $0.005 \mathrm{CR}+0.058 \mathrm{TATO}-3.865 \mathrm{Size}+\mathrm{e}$

Based on the above equation, it can be concluded that Profitability, Solvency, and Total Asset Turnover have a positive effect on stock prices. Meanwhile, Liquidity and Firm Size have a negative effect on stock prices.

\section{Uji t (Uji secara Parsial)}

Based on the results of the table of analysis results of the fix effect model test with data transformation, the sig t-test is obtained, namely:

1. ROA has a significant effect on stock prices so that $\mathrm{H} 1$ is accepted, which means ROA has a positive and significant effect on stock prices

2. DER has no significant effect on stock prices, then $\mathrm{H} 2$ is rejected, meaning that DER has a positive and insignificant effect on stock prices.

3. CR has no significant effect on stock prices, then $\mathrm{H} 3$ is rejected, meaning that $\mathrm{CR}$ has a negative and insignificant effect on stock prices. 
Watikah Sururi et.al. Analysis of the effect of financial performance, company size on stock prices with dividend policy as moderating variable in pharmaceutical companies listed on the Indonesia Stock Exchange 2013-2019.

4. TATO does not significantly affect stock prices, so $\mathrm{H} 4$ is rejected, meaning that TATO has a positive and insignificant effect on stock prices.

5. SIZE has a significant effect on stock prices, so that $\mathrm{H} 5$ is accepted, which means SIZE has a positive and significant effect on stock prices.

\section{F test (simultaneous test)}

\begin{tabular}{lrlr}
\multicolumn{4}{c}{ Table 7 F. Test } \\
\hline \hline R-squared & 0.894826 & Mean dependent var & 2.002101 \\
Adjusted R-squared & 0.864151 & S.D. dependent var & 0.222006 \\
S.E. of regression & 0.081826 & Akaike info criterion & -1.964177 \\
Sum squared resid & 0.321387 & Schwarz criterion & -1.453906 \\
Log likelihood & 76.87156 & Hannan-Quinn criter. & -1.763485 \\
F-statistic & 29.17055 & Durbin-Watson stat & 1.877564 \\
Prob(F-statistic) & 0.000000 & & \\
\hline \hline
\end{tabular}

Source: Results of EViews 10 software

Based on Table 7, it is known the value of Prob. (F-statistics), which is $0.000000<0.05$, it can be concluded that all independent variables, namely ROA, DER, CR, TATO, and SIZE, simultaneously have a significant effect on the stock price variable.

\section{Coefficient of Determination (R2)}

Based on Table 7, it is known that the coefficient of determination (R-squared) is 0.894826 , meaning that stock prices are influenced by ROA, CR, DER, TATO, and SIZE by $89.48 \%$ while other factors influence the remaining $10.52 \%$.

\section{Moderating Test}

With these results, it can be concluded that dividend policy can only moderate two variables, namely being able to moderate and strengthen the influence of solvency and liquidity on the company's stock price under study by weakening the activity ratio. However, dividend policy is not able to moderate profitability, activity ratio, and firm size.
Table 8 Moderating Test

\begin{tabular}{|c|r|r|r|r|}
\multicolumn{6}{|c|}{ Table 8 Moderating Test } \\
\hline Variable & Coefficient & \multicolumn{1}{l}{ Std. Error } & \multicolumn{1}{l}{ t-Statistic } & Prob. \\
\hline \hline C & 25853.11 & 7.743 .558 & 3.338 .661 & 0.0016 \\
\hline LNX1 & 6.384 .578 & 2.600 .233 & 0.245539 & 0.8070 \\
\hline Z & -173766.0 & 46801.32 & -3.712 .845 & 0.0005 \\
\hline M1 & -1.573 .168 & 8.666 .203 & -1.815 .291 & 0.0754 \\
\hline C & 33473.58 & 7.101 .956 & 4.713 .291 & 0.0000 \\
\hline LNX2 & 7.846 .008 & 5.583 .064 & 1.405 .323 & 0.1660 \\
\hline Z & -194411.9 & 44227.79 & -4.395 .695 & 0.0001 \\
\hline M2 & 8.570 .493 & 2.399 .292 & 3.572 .093 & 0.0008 \\
\hline C & 9.221 .432 & 5.112 .314 & 1.803 .769 & 0.0772 \\
\hline LNX3 & 34330.58 & 7.565 .122 & 4.538 .008 & 0.0000 \\
\hline Z & -177811.8 & 39431.26 & -4.509 .412 & 0.0000 \\
\hline M3 & 10346.40 & 2.044 .710 & 5.060 .082 & 0.0000 \\
\hline C & 15654.78 & 3.559 .408 & 4.398 .143 & 0.0001 \\
\hline LNX4 & 13806.17 & 10329.68 & 1.336 .554 & 0.1873 \\
\hline Z & -167005.9 & 47595.05 & -3.508 .893 & 0.0009 \\
\hline M4 & 6.315 .741 & 4.665 .087 & 1.353 .831 & 0.1818 \\
\hline C & 615198.0 & 920173.1 & 0.668568 & 0.5068 \\
\hline LNX5 & -183495.5 & 289953.8 & -0.632844 & 0.5297 \\
\hline Z & -182633.6 & 44799.75 & -4.076 .665 & 0.0002 \\
\hline M5 & 2.127 .797 & 7.288 .493 & 2.919 .392 & 0.0052 \\
\hline & Source: Results of EViews 10 software & \\
\hline & & & & \\
\hline
\end{tabular}

\section{CONCLUSION}

Based on the results of data analysis and research discussion, the following conclusions can be drawn:

1. Profitability has a positive and significant influence on the company's stock price in the pharmaceutical sector companies listed on the IDX in 2013 2019.

2. Solvency does not significantly affect the company's stock price in pharmaceutical sector companies listed on the IDX in 2013 - 2019.

3. Liquidity does not significantly affect the company's share price in pharmaceutical sector companies listed on the IDX in 2013 - 2019.

4. The activity ratio does not significantly influence the company's share price in the pharmaceutical sector companies listed on the IDX in 2013 - 2019.

5. Company size has a positive and significant influence on stock prices in pharmaceutical sector companies listed on the IDX in 2013 - 2019.

6. The dividend policy cannot moderate the effect of profitability on the company's share price in pharmaceutical sector companies listed on the IDX in 2013 - 2019.

7. Dividend policy can moderate the influence of the Solvency Effect on the company's stock price in pharmaceutical 
sector companies listed on the IDX in 2013 - 2019.

8. Dividend policy can moderate the effect of liquidity influence on the company's share price in pharmaceutical sector companies listed on the IDX in 2013 2019.

9. Dividend policy cannot moderate the influence of activity on the company's stock price in pharmaceutical sector companies listed on the IDX in 2013 2019.

10. The dividend policy cannot moderate the effect of company size on the company's share price in pharmaceutical sector companies listed on the IDX in 2013 - 2019.

\section{Research Limitations}

1. The objects of this research are pharmaceutical companies listed on the Indonesia Stock Exchange, which have ten companies, and the companies used as samples are limited to 9 companies that meet the predetermined criteria. It shows that the research sample used is not as large as the population. It does not fully describe the situation in the pharmaceutical sector companies listed on the Indonesia Stock Exchange.

2. The research period observed was too short, which was only for seven years from 2013 to 2019, so of course, it was still insufficient to describe the actual situation.

\section{Acknowledgement: None}

\section{Conflict of Interest: None}

\section{Source of Funding: None}

\section{REFERENCES}

1. Al-Tamimi, H. A., \& Kalli, A. B. (2009). Financial literacy and investment. The Journal of Risk Finance, 500-5016. doi:https://doi.org/10.1108/1526594091100 1402

2. Adipalguna, I. S., \& Suarjaya, A. G. (2016). Pengaruh Likuiditas, Solvabilitas, Aktivitas,Profitabilitas, Dan Penilaian Pasar
Terhadap Harga Saham Perusahaan LQ45 Di BEI. E-Jurnal Manajemen Unud, 76387668.

3. Arifin, N. F., \& Agustami, S. (2016). Pengaruh Likuiditas, Solvabilitas, Profitabilitas, Rasio Pasar, dan Ukuran Perusahaan Terhadap Harga Saham (Studi Pada Perusahaan Subsektor Perkebunan Yang Terdaftar Di Bursa Efek Indonesia Tahun 2010-2014). Jurnal Riset Akuntansi Dan Keuangan, 4(3), 1189-1210.

4. Brigham, E., \& Joel, F. (2010). Dasar-Dasar Manajemen Keuangan (Essential Of Financial Management). Florida: Salemba Empat.

5. Darmawan, A. (2016). Pengaruh Rasio Likuiditas, Solvabilitas Dan Profitabilitas Terhadap Harga Saham. Jurnal Setei Ekonomi, 25(1), 85-120.

6. Dessyana. (2016). Faktor-Faktor Yang Mempengaruhi Nilai Perusahaan Pada Perusahaan Manuaktur Yang Terdatar di Bursa Efek Indonesia dengan Profitabilitas Sebagai Variabel Intervening. Universitas Sumatera Utara: Tesis.

7. Dewi, L. (2015). Pengaruh Profitabilitas, Leverage Dan Likuiditas Terhadap Harga Saham Pada Perusahaan Industri Makanan Dan Minuman Di Bursa Efek Indonesia. .eJurnal Katalogis, 3(1), 114-125.

8. Erlina. (2011). Metodologi Penelitian : Untuk Akuntansi. Medan: Medan.

9. Gunarso. (2014). Laba Akuntansi, Leverage, dan Ukuran Laba Akuntansi, Leverage, dan Ukuran Indonesia. Jurnal Keuangan dan Perbankan, 16(1), 3-71.

10. Hidayat, W. W. (2019). Pengaruh ukuran perusahaan, eturn on equity dan leverage terhadap nilai perusahaan pada, perusahaan manufaktur di indonesia. jurnal ekonomi manajemen dan akuntansi, 21(1), 67-75.

11. Hussainey, K., Mgbame, C. O., \& ChijokeMgbame, M. A. (2011). Dividend Policy and Share Price Volatility: UK Evidence. Journal Accounting and Finance Decision.

12. Kasmir. ( 2015). Pengantar Manajemen Keuangan. Jakarta: Prenadamedia Group.

13. Meythi, En, T. K., \& Rusli, L. (2011). Pengaruh Likuiditas dan Profitabilitas Terhadap Harga Saham Perusahaan. Jurnal Bisnis Manajemen dan Ekonomi, 10(2), 2671-2684.

14. Mulyadi. (2010). Sistem Akuntansi (3 ed.). Jakarta: Salemba Empat. 
Watikah Sururi et.al. Analysis of the effect of financial performance, company size on stock prices with dividend policy as moderating variable in pharmaceutical companies listed on the Indonesia Stock Exchange 2013-2019.

15. Murniati, S. (2016). Effect of Capital Structure, Company Size, and Profitability on the Stock Price of Food and Beverage Companies Listed on the Indonesia Stock Exchange. 8, 23-29.

16. Octaviani, S., \& Komalasari, D. (2017). Pengaruh Likuiditas, Profitabilitas, Dan Solvabilitas Terhadap Harga Saham (Studi Kasus pada Perusahaan Perbankan yang Terdaftar di Bursa Efek Indonesia). Jurnal Akuntansi, 3(2), 77-89.

17. Pranata, H. C., \& Kurnia, R. (2013). Pengaruh Profitabilitas, Likuiditas, Solvabilitas, Dan Kebijakan Dividen Terhadap Harga Saham (Studi pada perusahaan go public yang terdaftar dalam Indeks Kompas100 periode 2009-2011). Ultima Accounting, 5(2), 81-97.

18. Prasetyorini, F. B. (2013). Pengaruh Ukuran Perusahaan, Leverage, Price Earning Ratio Dan Profitabilitas Terhadap Nilai Perusahaan. urnal Ilmu Manajemen (JIM), I, 1.

19. Rahmandia, F. (2013). Faktor-faktor yang Memengaruhi Harga Saham Perusahaan di Sektor Industri Barang Konsumsi yang Terdaf'tar di BEI Periode 2007-2011. Jurnal Mahasiswa Universitas Surabaya, 21(1), 121.

20. Ramadhani, I., \& Zannati, R. (2018). Pengaruh profitabilitas, likuiditas, solvabilitas. Jurnal Manajemen, 1(2), 59-68.

21. Ross, S., Westerfield, Radolph , W., \& Jordan, B. (2009). Pengantar Keuangan Perusahaan (Corporate Finance Fundamentals). JAKARTA: Salemba Empat.

22. Rudianto. (2013). Akuntansi Manajemen Informasi Untuk Pengambilan Keputusan Strategi. Jakarta: Penerbit Erlangga.
23. Sambelay, J., \& Rate, P. (2017). Analisis Pengaruh Profitabilitas Terhadap Harga Saham Pada Perusahaan Yang Terdaftar DI LQ45 Periode 2012-2016. Jurnal EMBA, 5(2), 753-761.

24. Stevani, O., \& Pernamasari, R. (2019). Study of firm value based on characteristic company : State owned enterprise listed indonesian stock exchange. Multidisciplinary Research, 5(8).

25. Sudana, I. M. (2015). Manajemen Keuangan Perusahaan (Vol. Edisi Kedua). Jakarta: Erlangga.

26. Suryawan, I. G., \& Wirajaya, I. A. (2017). Pengaruh Current Ratio, Debt To Equity Ratio Dan Return On Assets Pada Harga Saham. E-Jurnal Akuntansi Universitas Udayana, 21(2), 1317-1345.

27. Susilawati, C. (2012). Analisis Perbandingan Pengaruh Likuiditas, Solvabilitas dan Profitabilitas terhadap Harga Saham pada Perusahaan LQ 45. Jurnal Akuntansi, 4(2).

28. Utari, D., Purwanti, A., \& Prawironegoro, D. (2014). Manajemen Keuangan : Kajian Praktik dan Teori dalam Mengelola Keuangan Organisasi Perusahaan. Jakarta: Mitra Wacana.

How to cite this article: Sururi W, Yahya I, Abubakar E. Analysis of the effect of financial performance, company size on stock prices with dividend policy as moderating variable in pharmaceutical companies listed on the Indonesia Stock Exchange 2013-2019. International Journal of Research and Review. 2021; 8(7): 161-168. DOI: https://doi.org/10. 52403/ijrr.20210722 